\title{
Skull Morphometry of the Lion (Panthera leo), Dog (Canis Iupus familiaris) and Cat (Felis catus)
}

\author{
A. S. Saber ${ }^{1,2}$ and B.Gummow ${ }^{2,3}$ \\ ${ }^{1}$ Faculty of Veterinary Medicine, University of Sadat City, Sadat City, Egypt \\ ${ }^{2}$ Discipline of Veterinary Sciences, College of Public Health, Medical and Veterinary Sci- \\ ences, James Cook University, Townsville, Australia \\ ${ }^{3}$ Faculty of Veterinary Science, University of Pretoria, Pretoria, South Africa
}

Received October, accepted for publication December 2014

\section{Abstract}

The skull morphology of the lion (4), dog (15) and cat (4) are described and compared in this work. Measurements of their skull length, weight (without mandible), cranial length and width, facial length and width, skull index, cranial index, facial index, orbital index and cranial capacity are given. Correlations between these measurements were also examined for each species.

These results are discussed in terms of the usage of these morphometric measurements in several basic and clinical applications as well as in the intelligence status of these species. Four tables and three figures supported the results of this study.

Strong correlations $(R>0.7, R<-0.7)$ were seen between $63 \%$ of measurements in the lion's skull enabling regression models to be constructed that could be used to predict measurements such as skull weight if facial

J. Vet. Anat. width is known. This differed from the cat where $38 \%$ of measurements were correlated and the dog where only 3 parameters of measurements were correlated.

\section{Introduction}

The present study was carried out on four, big cat, lion skulls (Panthera leo) (family: Felidae, genus: panthera). For comparison, another 4 skulls of the family Felidae, the domestic cat (Felis catus), as well as 15 of the domestic dog (Canis lupus familiaris) were chosen.

The variability in the size and shape of the skull among domestic dogs and cats (Sisson, 1975; Evans, 1993 and Vilà et al., 1999) as well as among wild large cats is considerable compared to other mammalian species. Many parameters have been used to characterize the shape of the skulls in dogs and cats, of these the skull indices and ratios are effective tools for separating and defining the morpho-

Vol. 8, No. 1, (2015) 13 - 30 
logical types (Onar and Güneş, 2003). Künzel et al., (2003) confirmed three phenotypically different skull formations in the feline skull namely; round-shaped, triangular and cuneiform. In dogs, three skull types were recognized: the dolichocephalic, the mesanticephalic and the brachycephalic (Dyce et al., 2010, Evans, 1993 and Onar et al., 2003, 2012). Skull morphometric analysis has also helped discriminate tiger skulls of certain regions e.g. the mainland Asia tiger and the Suda Island tigers and their subspecies: Java/Bali, the Sumatra and the Siberian tiger (Mazàk, 2008).

Morphometric measurements thus help in understanding the skull morphology of different animal species, detecting skull deformations, and determining the cause of these deformations (Onar and Güneş, 2003).

The aim of this study is to add to the database the skull measurements of mixed Egyptian breeds of dogs and cats, and compare these measurements, indices and cranial capacity to a lion skull.

Keywords: morphometry, cranial capacity, lion, cat, dog, Egyptian.

\section{Material and Methods}

A skull of a lion (Panthera leo) that died in the National Circus in Egypt was brought to the Department of Anatomy and Embryology, Faculty of

J. Vet. Anat.
Veterinary Medicine, in Sadat City. The age of the animal was not known, however tearing of the teeth and loss of some of its teeth denotes an old animal. The skull was prepared using the boiling maceration technique for skeleton preparation described by Simoens et al. (1994). In addition, three clean African lion skulls kept in the Giza Zoo museum were also used in this study.

For comparison purposes, four skulls of domestic cats as well as fifteen skulls of domestic dogs kept in the museum of the Department of Anatomy and Embryology in the same Faculty in Sadat City were also used in this study.

The external measurements taken were: the skull length, skull width, cranial length, cranial width, facial length, facial width, skull weight, orbital height, orbital width, inter orbital distance (rostral, middle and caudal), mandibular length and mandibular weight.

The cranial as well as the orbital capacity of the lions, dog and cat skulls were determined and estimated using mustard seeds. For measuring the orbital capacity, foramina opening into the orbital cavity, were plugged with plasticin (plastic clay) and cotton wool. The communication between the orbital cavity and temporal fossa was blocked with cotton wool and the whole orbital cavity was lined with a very thin tissue paper. Then this cavi-

Vol. 8, No. 1, (2015) 13 - 30 
ty was filled with mustard seeds to the level of the orbital rim. The contents were emptied and measured in a measuring cylinder.

For measuring the cranial capacity, all the foramina of the cranial cavity were plugged with cotton wool. The cavity was then filled with mustard seeds through the foramen magnum up to its brim. The mustard seeds were then emptied into a measuring cylinder to get the capacity.

\section{Skull Parameters Measured:}

1) Cranial length: Distance between the highest point of the parietals to the middle of the rostral margin of the incisive bone.

\section{2) Cranial width: Distance between} two zygomatic arches.

\section{Skull length}

3) Skull base length: Distance between the midpoint of the dorsal margin of the foramen magnum to the level of the middle point on the rostral margin of the incisive bone.

4) Weight of the skull: Weight of the skull (excluding the mandible).

\section{Cranial Parameters Measured:}

1) Cranial length: Distance from the central point of the fronto-nasal suture to the middle point of the nuchal crest.
2) Cranial width: Maximum distance between the highest point of the parietal bones.

3) Cranial index $=\frac{\text { Cranial width }}{\text { Cranial length }} \times 100$ (Miller et al., 1964)

4) Capacity of the cranial cavity

\section{Orbital parameters Measured:}

1) Orbital length: The perpendicular distance between the supraorbital and infraorbital margins of the orbit.

2) Orbital width: The horizontal distance between the rostral and caudal margins of the orbital rim.

3) Orbital index $=\frac{\text { Orbital width }}{\text { Orbital length }} \times 100$ (Miller et al., 19964)

4) Inter-orbital distance:

ii. At middle level: Distance between the supraorbital borders of orbit on either sides.

iii. At caudal level: Distance between the junctions of the zygomatic bone at the caudal margin of the orbit on either side. 
5) Orbital capacity

\section{Facial Parameters Measured:}

1) Facial length: Distance from the fronto-nasal suture to the centre of the incisive bone.

2) Facial width: Distance between the caudal extents of the orbital rims.

3) Facial index $=\frac{\text { Facial width }}{\text { Facial length }} \times 100$ (Miller et al., 1964)

All the obtained measurements were expressed as mean $\pm S D$ as well as minimum and maximum values in Tables (1-4)

\section{Data Analysis}

The craniometric measurements were taken using a normal caliper. Photographs were taken by a Samsung digital camera WB 700. Nomina Anatomica Veterinaria (2005) was utilized for denominating the anatomical terms in the study.

Associations between morphometric measurements within each of the species examined were compared using the Pearson product-moment correlation coefficient (van Belle, et al., 2004). Analysis was carried out in MS Excel 2010. Coefficients > 0.7 were considered to have a strong positive correlation and coefficients <0.7 were considered to have a strong negative coefficient. Linear regression models (van Belle et al., 2004) were used to model the linear relationship between selected measure- ments that had a particularly strong correlation.

\section{Results \& Discussion}

\section{Techniques used:}

Mustard seeds have been used for measuring the cranial and orbital capacities by many authors because of their rounded shape and small size (Saber, 1989 and Sarma, 2006). However, some authors used sesame seeds (Rao, 1967), rice grains (Olopade and Onwuka, 2005) and sand (Mihayalov et al., 2013). More modern techniques such as computed tomographic images and scanograms as well as x-ray images of live animals have been also used for measuring, calculating and analyzing the different parameters and indices (Onar et al., 2002; Alpak, 2003 and Kock et al., 2012). Modern techniques are more accurate in measuring and analyzing parameters on a plane surface, but less accurate in determining the cranial and orbital volumes, which is why mustard seeds were used in this case.

\section{Morphometric measurements:}

The results of this study were expressed as mean, standard deviation (SD) of the mean with the maximum and minimum values. (Tables 1-4)

The mean skull length of the lion, dog and cat was $39.75 \pm 1.04,20.02 \pm 1.36$ and $8.4 \pm 1.5 \mathrm{~cm}$, while the skull width was $28 \pm 2.16, \quad 10.04 \pm 0.56$ and $6.8 \pm 1.4 \mathrm{~cm}$ respectively (Table $1-3$ ). 
The mean cranial length of the lion's, dog's and cat's skulls were $18.86 \pm 4.77,5.96 \pm 0.63$ and $3.4 \pm 0.4$ $\mathrm{cm}$, while the mean cranial width was $11.85 \pm 1.98,5.13 \pm 0.34$ and $4.1 \pm 0.2$ cm respectively (Table 1 ).

The mean facial length the lion's, dog's and cat's skulls were $17.88 \pm 5.59,14.16 \pm 0.89$ and $5.0 \pm 1.5$ $\mathrm{cm}$, while the mean facial width was $17.75 \pm 5.19,5.37 \pm 0.35$ and $5.9 \pm 1.2$ $\mathrm{cm}$ respectively (Table 1 ).

The mean cranial capacity of the same animal species (lion, dog and cat) was $207.4 \pm 24.49,86.4 \pm 11.87$ and $20.8 \pm 1.95 \mathrm{cc}$ respectively (Table1). A comparison between the cranial capacities of different animal species is listed in Table (3).

In the same animals of this study (lion, dog and cat), the mean cranial index was $64.07 \pm 8.27,90.98 \pm 10.04$ and $121.24 \pm 18.29$ while the mean facial index was 113.9 \pm 58.57 , $37.99 \pm 3.06$ and $121.67 \pm 19.51$ respectively. The mean orbital index was $72.55 \pm 3.04, \quad 89.67 \pm 9.88$ and $83.48 \pm 10.61$ respectively (Table 2 ).

Zuccarelli (2004) examined 75 lion skulls (57 wild and 12 captive lions) and recorded 21 different measurements from the maxillary and mandibular regions of the skulls. He estimated the overall length of the skulls as $312.7,303.5 \mathrm{~mm}$ and the overall width of the skulls as 204.6, 205.2 spectively.

The calculations of 14 indices and ratios were accomplished using the craniometric measurements in dogs (Sisson, 1975; Komeyli, 1984; Von Brehm et al., 1985; Betti, 1990; Lignereux et al., 1991, 1992; Regedon et al., 1991; Evans, 1993; Simoens et al., 1994; Onar et al., 1997, 2001, 2002; Onar, 1999; Janeczek et al., 2005).

Many studies of canine skull morphometry have been performed (Hidaka et al., 1998, Kauhala et al., 1998; Onar, 1999; Onar et al., 1997, 2001; Yildiz et al., 1993) and have yielded morphometric values relevant to the skull shape.

Monfared (2013 a,b,c,) estimated 66.37 for the adult Iranian mixedbreed dogs cranial index, 71.28 for the Golden Jackal and 55.55 for the Persian cat skull, respectively. Karimi et al., (2011) estimated $52.76 \pm 1.13$ as the cranial index and $130.86 \pm$ 11.55 for the cranial volume in Mehraban Sheep.

Onar et al., (2012) mentioned $54.25 \pm 4.29$ and $57.13 \pm 3.64$ as skull indices differentiating the dolichocephalic and the mesocephalic skulls of Byzantine dogs (500 skulls).

Künzel et al., (2003) mentioned that the round skull type of cats was characterized by an increase in height of 
the braincase. Moreover, Hain (1986) reported that the Persian skulls were significantly wider than those of the Siamese and European Shorthair as well.

The skull, facial and cranial indices of Tibetan gazelle were $43.22 \pm 0.44$, $58.77 \pm 0.30$ and $11.37 \pm 1.24$ respectively (Zhu, 2012). In the immature one-humped camel skull the facial indices for the females and males were 96.4 and 96.2 respectively (Yahaya et al., 2012). The facial and cranial indices of the Kagani goat were $138.48 \pm 0.57$ and $113.0 \pm 0.54$ respectively (Sarma, 2006) (Table 4). Schmidt et al., (2011) mentioned that in dogs a high index indicates a wider braincase in relation to length (higher grade of brachyocephaly).

Archana et al. (2006) mentioned 6X5 $\mathrm{cm}$ as the dimension of the Himalayan leopard orbital cavity, $2.00 \mathrm{~kg}$ for the mass of head, $27.00 \mathrm{~cm}$ and 15.5 $\mathrm{cm}$ for the length and width of head respectively. Mihajlov and Dimitrov (2010) studied 7 species from the Felidae family and concluded that the tiger possessed the greatest volume and length of cranial cavity, while the lion possessed the greatest head length, width and height.

The orbital index in the lion, dog and cat in this study was $72.55 \pm 3.04$, $89.67 \pm 9.88$ and $83.48 \pm 10.61$ and the average orbital capacity was 80.5 , 10.9 and $3.8 \mathrm{~cm}^{3}$ respectively. Karimi et al., (2011) mentioned 21.46 \pm 0.68 J. Vet. Anat. as the orbital index in Mehraban Sheep.

\section{Correlations:}

Table (6) shows that 66 of the 105 pairs $(63 \%)$ of morphometric measurements in the lion's skull are strongly correlated either positively or negatively. This suggests that changes in dimensions of one part of the skull are uniformly reflected in other parts of the skull. Knowing this could be useful in determining the parameters of the skull if only portions of the skull are available, as might be the case with archaeology. Some of the measurements have perfect linear relationships such as Facial width: Skull weight, Facial width: Orbital height and Skull weight: Orbital height. The practical application of this is that regression models can be used to accurately predict the one measurement if the other is known. For example if the facial width is know it is possible to predict the skull weight using the regression model Skull weight = 214+84(facial width). Orbital Height appears to be particularly well correlated to a number of other morphometric measurements (Table 6).

Examination of the correlation matrix for the cat (Table 7) also shows a number of measurements to be strongly correlated. However the proportion of pairs that are strongly correlated is lower than for the lion skull $(35 / 91=38 \%)$ and most of these are positive correlations. There was still a strong correlation between facial 
width and skull weight (0.86) but less so than for the lion. Correlations with orbital height were more variable.

In the dog only three pairs of measurements had strong correlations (Table 8). These were skull length with facial length and orbital capacity, and caudal intra-orbital distance with middle intra-orbital distance. These correlations are not unexpected. What is surprising is the lack of meaningful correlations between the other measurements when compared to lions and cats. There was a difference in sample sizes between the number of dog skulls $(n=15)$ compared to the number of lion and cat skulls $(n=4)$ and initially it was thought that the increase in sample size might have brought more variability into the data accounting for the poor correlations. However when covariances were calculated (SD/mean) there was not much difference in covariance between the three groups (Table 9) making variability in the data unlikely as the reason for the poor correlations seen in the dog skulls.

\section{Skull capacity:}

Hajnis (1962) stated that the skull capacity is not dependant on the form of the skull. In the domestic cat, the neurocranial volume was $28 \pm 0.97 \mathrm{ml}$, neurocranial length was $6.63 \pm 0.77$ $\mathrm{cm}$, and the neurocranial height and index were $3.32 \pm 0.38 \mathrm{~cm}$ and $49.83 \%$, respectively (Uddin et al., 2013).

J. Vet. Anat.
Hieck and Dougherty (2013) estimated the cranial capacity and cranial index for the bull, deer, pig, raccoon, cat, badger, gray fox, squirrel, Prairie dog, marmot, jack rabbit and human, postulated that predators, in comparison to prey, were of a higher intelligence.

\section{Conclusion:}

The data obtained in this study are of great significance in paleontological studies and can be compared to cranial measurements of fossils. In addition, it provides baseline data on the skull osteometry, which is useful for comparative anatomical and developmental studies and is important also in the clinical treatment of diseases.

\section{References}

Alpak, H. (2003): Morphometry of the mandible of German shepherd dog (Alsatian) puppies using computed tomographic analysis. Israel Journal of Veterinary Medicine. Vol. 58 (1): 15-17.

Archana, D.; Scharma, N.; Rajput, R.; Kishtwaria, R.S.; Bhardwaj, R.L. and Sidhakar, L.S. (2006): Anatomy of north-western Himalayan leopard. Indian Journal of Animal Sciences 76: 616-617.

Betti, E., (1990): Ce'phalome'trie Compare'e chez le Chien. The'se Ve't, Nantes, pp. 1-81.

Vol. 8, No. 1, (2015) 13 - 30 
Dyce, K.M.; Sack, W.O. and Wensing, C.J.G. (2010): Textbook of Veterinary Anatomy, $4^{\text {th }}$ ed. Saunders, Elsevier.

Evans, H.E. (1993): The skeleton. In: Evans HE, editor. Miller's anatomy of the dog. $3^{\text {rd }}$ ed. Philadelphia: W.B. Saunders Co. p 122-166.

Hajnis, K. (1962): Evaluation of different methods of calculation of skull capacity for lineal Measurements. Ceskolov.Merfol., 10:220-233- cited by G.S.Rao(1967).

Hain, E. (1986): Untersuchung panmiktischer Katzenpopulationen zur multiplen Farbgenallelie und zur rassischen Variation einiger Schädel merkmale. Thesis in Veterinary Medicine, Tierärtzttliche Hochschule. Hannover.

Hidaka, S.; M. Matsumoto; H. Hiji; S. Ohsako; and H. Nishinakagawa, (1998): Morphology and morphometry of skulls of Raccoon dogs, Nyctereutes procyonoides and Badgers, Meles meles. J. Vet. Med. Sci. 60, 161-167.

Hieck, K. and Dougherty, M. (2013): Finding the intelligence of an animal. Field study . presented to STEM Teacher Academy, Rider University. http://riderstem.weebly.com/cranialvolume-intelligence.html

Janeczek, M.; A. Chro' szcz; M. Wojnar; and N. Pospieszny,(2005):

J. Vet. Anat.
Analizakranio-metryczna czaszek pso'w rasy American staffordshire terrier (AST). Medycyna Wet. 61, 789-791.

Kauhala, K.; Viranta, S.; Kishimoto, M.; Helle, E. and Obara, I. (1998): Skull and tooth morphology of Finnish and Japanese raccoon dogs. Ann Zool Fennici 35: 1-16.

Karimi, I.; Onar, V.; Pazvant, G.; Hadipour, M.; and Mazaheri, Y. (2011): The Cranial Morphometric and Morphologic Characteristics of Mehraban Shep in Western Iran. Global Veterinaria 6 (2): 111-116.

Koch, D.A.; Wiestner, T.; Balli, A.; Montavon, P.M.; Michel, E.; Schart, G. And Arnold, S. (2012): Proposal for a new radiological index to determine skull conformation in the dog. Schweizer Archiv für Tierheilkunde, 154 (5): 217-220.

Komeyli, H. (1984): Nasennebenhöhlen bei dolicho-, meso-, und brachyzephalen Hunden unter besonderer Berücksichtigung der rassespezifischen Schädelformen. Thesis in Veterinary Medicine, Tierärtzttliche Hochschule. Giessen.

Künzel W.; Breit, S. and Oppel, M. (2003): Morphometric investigation of breed-specific features in feline skulls and consideration on their functional implication. Anat. Histol. Embryol., 32(4): 218-223. 
Lignereux, Y.; Regedon, S. and Pavaux, C. I. (1991): Typologiecéphalique canine. Revue Méd. Vét. 142: 469-480.

Lignereux, Y.; Regedon, S.; Personnaz, B. and Pavaux, C. I. (1992): Typologie céphalique du Chien et ostéoarchéologie: àpropos d'une population canine du XVIle siécle Toulousain. Revue Méd. Vét. 143: 139-149.

Mazák, J.H. (2008): Craniometric variation in the tiger (Panthera tigris): Implications for patterns of diversity, taxonomy and conservation. Mammalian Biology; 75(1): 45-68.

Mihaylov, R. and Dimitrov, $\mathbf{R}$. (2010): Volume and sizes of the cranial cavity in some animals from Felidae family. Animal Science, Vol.47 (3): $67-75$ (Bg).

Mihaylov, R.; Dimitrov, R.; Raichev, E.; Kostov, D.; Stamatova-Yiovcheva, K.; Zlatanova, D. and Bivolarski, B. (2013): Morphometric Features of the Head Skeleton in Brown Bear (Ursus Arctos) in Bulgaria. Bulgarian Journal of Agricultural Science, 19 (2): 331-337.

Miller,M.S.; Christensen,G.C; and Evans, H.E. (1964): The skeletal system, skull. In anatomy of Dog. Pp. 649. W.B.Saunders Co., Philadelphia.
Monfared, A.L. (2013a): Anatomical study of the skull of the adult dogs and its Clinical Value During Regional Anesthesia. Global Veterinaria 10 (4): 459-463.

Monfared, A.L. (2013b): Macroanatomical Investigation of the Skull of Golden Jackal (Canis aureus) and its clinical Application during Regional Anethesia. Global Veterinaria 10 (5): 547-550.

Monfared, A.L. (2013c): Anatomy of the Persian Cat's skull and its clinical value during regional anesthesia. Global Veterinaria 10 (5): 551-555.

\section{Nomina Anatomica Veterinaria} (2012): NAV, $5^{\text {th }}$ ed. (revised). Prepared by Inter-national Committee on Veterinary Gross Anatomical Nomenclature (ICVGAN). Authorized by the General assembly of the World Association of Veterinary Anatomists (WAVA), Knoxville. TN (USA) 2003.

Olopade J.O. and Onwuke, S.K. (2005): Morphometric study of the skull of the West African Dwarf goat from South West Nigeria. Nigerian Veterinary Journal, Vol.26(2): 18-21.

Onar, V. (1999): A morphometric study on the skull of German shepherd dog (Alsatian). Anat. Histol. Embryol. 28: 253-256.

Onar, V.; Armutak, A.; Belli, O. and Konyar, E. (2002): Skeletal remains 
of dogs unearthed from the Van-

Yoncatepe necropolises. Int. J. Osteoarchaeol. 12, 317-334.

Onar, V.; Çakirlar, C.; Janeczek, M. and Kiziltan, Z. (2012): Skull Typology of Bezantine dogs from the Theodosius Harbour at Yenikapi, Istanbul, Anat. Histol. Embryol. 41 (5): 341-52.

Onar, V. and Güneş, K. (2003): On the variability of skull shape in German shepherd (Alsatian) puppies. Anat. Rec., Part A, 272A: 460-466.

Onar, V.; Kaheciodlu, K.O. and Cebi, V. (2002): Computed tomographic analysis of the cranial cavity and neurocranium in the German shepherd dog (Alsatian) pippies. Veterinarski Arhiv 72 (2): 57-66.

Onar, V.; Mutus, R. and Kahvecioğlu, K. O. (1997): Morphometric analysis of the foramen magnum in German Shepherd dogs (Alsatians). Ann. Anat. 179: 563-568.

Onar, V.; Özcan, S. and Pazvant, G. (2001): Skull typology of adult male kangal dogs. Anat. Histol. Embryol. 30: 41- 48.

Rao, G.S. (1967): Cranial capacity of adult bovine skull. Journal of the Anatomical Society of India, 16: 121-127.

Regedon, S.; Franco, A.; Garin, J.M.; Robina, A.; Lignereux Y. (1991):Computerized tomographic determination of the cranial volume of the dog applied to racial and sexual differentiation. Acta Anat. 142, 347350.

Saber, A. S. (1989): Cranial capacity of sheep and goat. Assiut Vet. J. Vol. 21, No 42: 1-6.

Sarma, K. (2006): Morphological and Craniometrical Studies on the skull of Kagani Goat (Capra hircus) of Jammu Region. Int. J. Morphol. 24(3): 449455.

Sandhu P.S. and Dhingra L.D. (1986): Cranial capacity of Indian camel. Indian Journal of Animal Science, 56: 870-872.

Schmidt, M.J.; Neumann, A.C.; Amort, K.H.; Failing, K. and Kramer, M. (2011): Cephalometric Measurements and Determination of General Skull Type of Cavalier King Charles Spaniels. Vet Radiol Ultrasound. 2011 Jul-Aug; 52(4):436-40.

Simoens, R., Poles, R. and lauwers, H. (1994): Morphometric analysis of foramen magnum in Pekingese dogs. American Journal of Veterinary Research, 55: 33-39.

Sisson, S., (1975): Carnivore osteology. In: The Anatomy of the Domestic Animals, Vol. 2, $5^{\text {th }}$ ed. (S. Sisson and J. D. Grossman eds.). Philadelphia, PA: Saunders Company. 
Uddin, M.; Sarker, M.H.R.; Hossain, M.E.; Islam, M.S.; Hossain, M.B. and Shil, S.K. (2013): Morphometric investigation of neurocranium in domestic cat (Felis catus). Bangl. J. Vet. Med., 11(1): 69-73.

van Belle, G.; Fisher, L.D.; Heagerty, P.J. and Lumley, T. (2004): Biostatistics. A methodology for Health Sciences. John Wiley \& Sons, Inc. Hoboken, New Jersey).

Vilà, C.; Maldonnando, J.F. and Wayne, R.K. (1999): Phylogenetic relationships evaluation, and genetic diversity of domestic dog. J. Hered, 90:71-77.

Von Brehm, H.; Loeffler, K. and Komeyli, H. (1985): Schädelformen beim Hund. Anat. Histol. Embryol. 14: 324-331.
Wikipedia, the free encyclopedia (retrieved: 4/12/2008).

Yahaya , A.; Olopade, J.O.; Kwari, D. and Wiam, I.M. (2012): Osteometery of the skull of one-humped camels. Pert I: Immature animals. IJAE Vol. 117, n: 23-33.

Yildiz, B.; Serbest, A.; Yilmaz, O. and Kirbiyik, H. (1993): The comparison of the head measures of Turkish and German shepherd dog breeds. J Fac Vet Med Univ Uludag, 1: 35-39.

Zhu, L (2012): Craniometrical studies on the skull of Tibetan gazelle (Procapra picticaudata). Int. J. Morphol. 30 (1): 196-198.

Zuccarelli Micah D. (2003): Comparative morphometric analysis of captive vs. wild African lion (Panthera leo) skulls. Bios, Vol.75, No. 4: 131138

Table (1): Mean measurements, Standard Deviation (SD), with the Minimum (Min) and Maximum (Max) values of the Lion skulls.

\begin{tabular}{|c|l|c|c|c|c|}
\hline No. & \multicolumn{1}{|c|}{ Parameters } & Mean & SD & Min & Max \\
\hline 1 & Skull length $(\mathrm{cm})$ & 39.75 & 1.04 & 38.50 & 41.00 \\
\hline 2 & Skull width $(\mathrm{cm})$ & 28 & 2.16 & 25.00 & 30.00 \\
\hline 3 & Cranial length $(\mathrm{cm})$ & 18.88 & 4.77 & 13.00 & 23.00 \\
\hline 4 & Cranial width $(\mathrm{cm})$ & 11.85 & 1.98 & 8.90 & 13.00 \\
\hline 5 & Facial length $(\mathrm{cm})$ & 17.88 & 5.95 & 11.00 & 18.00 \\
\hline 6 & Facial width $(\mathrm{cm})$ & 17.75 & 5.19 & 10.00 & 20.00 \\
\hline 7 & Skull weight $(\mathrm{gm})$ & 1703 & 437.06 & 1050.00 & 1950.00 \\
\hline 8 & Orbital capacity (gm) & 80.5 & 21.44 & 56.25 & 100.00 \\
\hline 9 & Orbital height $(\mathrm{cm})$ & 7.75 & 0.50 & 7.00 & 8.00 \\
\hline 10 & Orbital width $(\mathrm{cm})$ & 5.625 & 0.48 & 5.00 & 6.00 \\
\hline 11 & Interorbital distance (rostral) $(\mathrm{cm})$ & 13.55 & 3.03 & 10.20 & 17.00 \\
\hline 12 & Interorbital distance (middle) $(\mathrm{cm})$ & 8.4 & 0.71 & 7.60 & 9.00 \\
\hline 13 & Interorbital distance (caudal) $(\mathrm{cm})$ & 15.25 & 3.86 & 11.00 & 18.00 \\
\hline 14 & Cranial capacity (cc) & 207.4 & 24.49 & 181.25 & 218.75 \\
\hline 15 & Mandibular length (cm) & 29.53 & 0.64 & 28.80 & 30.00 \\
\hline
\end{tabular}


Skull Morphometry of the lion, dog and cat

Saber and Gummow

Table (2): Mean measurements, Standard Deviation (SD), with the Minimum (Min) and Maximum (Max) values of the dog skulls.

\begin{tabular}{|c|l|c|c|c|c|}
\hline No. & \multicolumn{1}{|c|}{ Parameters } & Mean & SD & Min & Max \\
\hline 1 & Skull length $(\mathrm{cm})$ & 20.02 & 1.36 & 18.4 & 23.7 \\
\hline 2 & Skull width $(\mathrm{cm})$ & 10.04 & 0.56 & 9 & 10.9 \\
\hline 3 & Cranial length $(\mathrm{cm})$ & 5.96 & 0.63 & 4.8 & 7.1 \\
\hline 4 & Cranial width $(\mathrm{cm})$ & 5.13 & 0.34 & 4.5 & 5.8 \\
\hline 5 & Facial length (cm) & 14.16 & 0.89 & 12.3 & 15.6 \\
\hline 6 & Facial width (cm) & 5.37 & 0.35 & 4.8 & 6 \\
\hline 7 & Skull weight (gm) & 165.47 & 47.25 & 100 & 275 \\
\hline 8 & Orbital capacity (gm) & 10.9 & 3.21 & 7.5 & 18.5 \\
\hline 9 & Orbital height (cm) & 3.3 & 0.28 & 2.7 & 3.6 \\
\hline 10 & Orbital width (cm) & 2.8 & 0.18 & 2.4 & 3 \\
\hline 11 & $\begin{array}{l}\text { Interorbital distance (rostral) } \\
\text { (cm) }\end{array}$ & 4.35 & 0.51 & 3 & 4.9 \\
\hline 12 & $\begin{array}{l}\text { Interorbital distance (middle) } \\
\text { (cm) }\end{array}$ & 3.59 & 0.87 & 3 & 5.8 \\
\hline 13 & $\begin{array}{l}\text { Interorbital distance (caudal) } \\
\text { (cm) }\end{array}$ & 5.11 & 39.66 & 4.2 & 115 \\
\hline 14 & Cranial capacity (cc) & 86.4 & 11.87 & 60 & 115 \\
\hline
\end{tabular}

Table (3): Mean measurements, Standard Deviation (SD), with the Minimum (Min) and Maximum (Max) values of the cat skulls.

\begin{tabular}{|c|l|c|c|c|c|}
\hline No. & \multicolumn{1}{|c|}{ Parameters } & Mean & SD & Min & Max \\
\hline 1 & Skull length (cm) & 8.4 & 1.5 & 6.3 & 9.5 \\
\hline 2 & Skull width (cm) & 6.8 & 1.4 & 5 & 8.5 \\
\hline 3 & Cranial length (cm) & 3.4 & 0.4 & 3 & 4 \\
\hline 4 & Cranial width (cm) & 4.1 & 0.2 & 3.8 & 4.3 \\
\hline 5 & Facial length (cm) & 5.0 & 1.5 & 3 & 6.5 \\
\hline 6 & Facial width (cm) & 5.9 & 1.2 & 4.2 & 7 \\
\hline 7 & Skull weight (gm) & 32.5 & 12.6 & 20 & 50 \\
\hline 8 & Orbital capacity (gm) & 3.8 & 1.6 & 1.8 & 5.5 \\
\hline 9 & Orbital height (cm) & $\mathbf{2 . 8}$ & 0.65 & 2 & 3.5 \\
\hline 10 & Orbital width (cm) & $\mathbf{2 . 3}$ & 0.27 & 1.8 & 2.5 \\
\hline 11 & $\begin{array}{l}\text { Interorbital distance (rostral) } \\
\text { (cm) }\end{array}$ & $\mathbf{2 . 4}$ & 4.14 & 1.8 & 13.8 \\
\hline 12 & $\begin{array}{l}\text { Interorbital distance (middle) } \\
\text { (cm) }\end{array}$ & $\mathbf{1 . 6}$ & 0.23 & 1.2 & 1.8 \\
\hline 13 & $\begin{array}{l}\text { Interorbital distance (caudal) } \\
\text { (cm) }\end{array}$ & $\mathbf{2 . 8}$ & 0.18 & 2.6 & 3 \\
\hline 14 & Cranial capacity (cc) & $\mathbf{2 0 . 8}$ & 1.95 & 17.5 & 22.5 \\
\hline
\end{tabular}


Skull Morphometry of the lion, dog and cat

Saber and Gummow

Table (4): Means of the cranial, orbital, facial and skull/cephalic indices in lion, dog and cat, one-humped camel (Yahaya et al, 2012), Tibetan Gazelle (Zhu, 2012), German Shepherd dog (Onar, 1999), Mehraban Sheep (Karimi et al., 2011), golden jackal (Monfared, 2013b)

\begin{tabular}{|c|c|c|c|c|c|c|c|c|}
\hline Parameter & Lion & Dog & Cat & Camel & $\begin{array}{l}\text { Tibetan } \\
\text { Gazelle }\end{array}$ & $\begin{array}{c}\text { Ger- } \\
\text { man } \\
\text { She- } \\
\text { pherd } \\
\text { dog }\end{array}$ & $\begin{array}{c}\text { Mehra- } \\
\text { ban } \\
\text { Sheep }\end{array}$ & $\begin{array}{l}\text { Golgen } \\
\text { Jackal }\end{array}$ \\
\hline $\begin{array}{l}\text { Cranial In- } \\
\text { dex }\end{array}$ & $\begin{array}{c}64.07 \pm \\
8.27\end{array}$ & $\begin{array}{c}90.96 \\
\pm 10.04\end{array}$ & $\begin{array}{r}121.24 \\
\pm 18.29\end{array}$ & $\begin{array}{c}41.42 \pm \\
0.43\end{array}$ & $\begin{array}{c}58.37 \pm \\
0.80\end{array}$ & 73.24 & $\begin{array}{c}52.76 \pm \\
1.13\end{array}$ & 71.28 \\
\hline Orbital Index & $\begin{array}{c}72.55 \pm \\
3.04\end{array}$ & $\begin{array}{l}89.67 \\
\pm 9.88\end{array}$ & $\begin{array}{c}83.48 \\
\pm 10.61\end{array}$ & - & - & - & $\begin{array}{c}21.46 \pm \\
0.68\end{array}$ & - \\
\hline Facial Index & $\begin{array}{c}113.9 \pm \\
58.57\end{array}$ & $\begin{array}{l}37.99 \\
\pm 3.06\end{array}$ & $\begin{array}{l}121.67 \\
\pm 19.51\end{array}$ & $\begin{array}{c}96.35 \pm \\
0.95\end{array}$ & $\begin{array}{c}116.37 \pm \\
1.24\end{array}$ & 133.13 & $\begin{array}{c}85.44 \pm \\
1.89\end{array}$ & - \\
\hline $\begin{array}{l}\text { Skull/cephali } \\
\text { c Index }\end{array}$ & $\begin{array}{l}71.28 \\
\pm 2.71\end{array}$ & $\begin{array}{l}24.86 \\
\pm 2.85\end{array}$ & $\begin{array}{l}80.79 \\
\pm 6.08\end{array}$ & $\begin{array}{c}40.99 \pm \\
0.33\end{array}$ & $\begin{array}{c}43.22 \pm 0 \\
44\end{array}$ & 58.43 & $\begin{array}{c}53.57 \pm \\
3.26\end{array}$ & - \\
\hline
\end{tabular}

Table (5): The average cranial capacity of some animal species and man

\begin{tabular}{|c|c|c|}
\hline Authors & $\begin{array}{l}\text { Animal } \\
\text { Species }\end{array}$ & $\begin{array}{l}\text { Average cranial capacity } \\
\text { (cc) }\end{array}$ \\
\hline Miller et al. & Dog & $82-92-104$ \\
\hline (1967) & Ox & $440 \pm 39.50$ \\
\hline (1967) & Buffalo & $627.45 \pm 62.12$ \\
\hline Sandhu \& Dhingra & Camel & $587.14 \pm 14.89$ \\
\hline$(1988)$ & Sheep & $122.154 \pm 5.355$ \\
\hline (1988) & Goat & $95.846 \pm 8.119$ \\
\hline Wikipedia, the free encyclopedia & Orangutans & $275-500$ \\
\hline Wikipedia, the free encyclopedia & Chimpanzees & $275-500$ \\
\hline Wikipedia, the free encyclopedia & Gorillas & $340-752$ \\
\hline Wikipedia, the free encyclopedia & Humans & $1100-1700$ \\
\hline Wikipedia, the free encyclopedia & Neanderthals & $1200-1700$ \\
\hline Sarma & Kagani goat & 113 \\
\hline Mihaylov et al., & Brown bear & $343 \pm 13.86$ \\
\hline
\end{tabular}


Table (6): Correlation of morphometric measurements of the Lions skull $(n=4)$

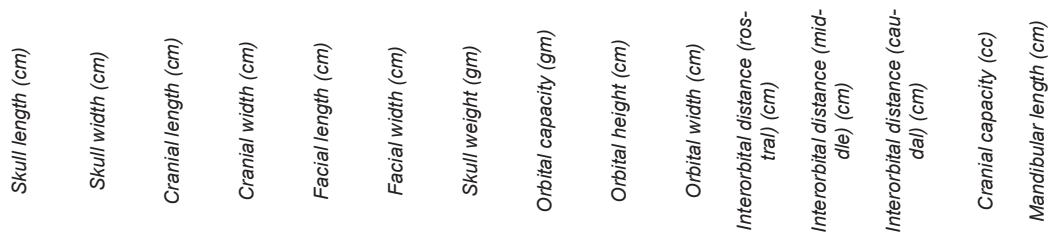

\begin{tabular}{|c|c|c|c|c|c|c|c|c|c|c|c|c|c|c|c|}
\hline Skull length $(\mathrm{cm})$ & $\begin{array}{r}1 \\
0.8\end{array}$ & & & & & & & & & & & & & & \\
\hline \multirow[t]{2}{*}{ Skull width (cm) } & 2 & 1 & & & & & & & & & & & & & \\
\hline & 0.3 & 0.7 & & & & & & & & & & & & & \\
\hline \multirow[t]{2}{*}{ Cranial length $(\mathrm{cm})$} & 4 & 8 & 1 & & & & & & & & & & & & \\
\hline & 0.7 & 0.9 & 0.8 & & & & & & & & & & & & \\
\hline \multirow[t]{2}{*}{ Cranial width $(\mathrm{cm})$} & 3 & 2 & 8 & 1 & & & & & & & & & & & \\
\hline & $\begin{array}{r}-\overline{9} \\
6\end{array}$ & $\begin{array}{r}- \\
0.7 \\
7\end{array}$ & $\begin{array}{r}- \\
0.4 \\
1\end{array}$ & $\begin{array}{r}- \\
0.7 \\
9\end{array}$ & 1 & & & & & & & & & & \\
\hline Facial length (cm) & $\begin{array}{r}0.7 \\
6\end{array}$ & $\begin{array}{r}0.8 \\
9\end{array}$ & $\begin{array}{r}0.8 \\
4\end{array}$ & $\begin{array}{r}0.9 \\
9\end{array}$ & $0 . \overline{8}$ & 1 & & & & & & & & & \\
\hline Facial width $(\mathrm{cm})$ & 0.8 & 0.8 & 0.7 & 0.9 & $0 . \overline{8}$ & 1.0 & & & & & & & & & \\
\hline \multirow[t]{2}{*}{ Skull weight (gm) } & 1 & $\begin{array}{l}9 \\
-\end{array}$ & $\begin{array}{r}9 \\
-\end{array}$ & $\begin{array}{l}8 \\
-\end{array}$ & 8 & $\begin{array}{l}0 \\
-\end{array}$ & $\begin{array}{l}1 \\
-\end{array}$ & & & & & & & & \\
\hline & $\begin{array}{r}0.0 \\
1\end{array}$ & $\begin{array}{r}0.5 \\
7\end{array}$ & $\begin{array}{r}0.9 \\
0\end{array}$ & $\begin{array}{r}0.6 \\
1\end{array}$ & $\begin{array}{r}0.0 \\
0\end{array}$ & $\begin{array}{r}0.5 \\
3\end{array}$ & $\begin{array}{r}0.4 \\
5\end{array}$ & 1 & & & & & & & \\
\hline Orbital capacity (gm) & $\begin{array}{r}0.8 \\
0\end{array}$ & $\begin{array}{r}0.9 \\
3\end{array}$ & $\begin{array}{r}0.8 \\
2\end{array}$ & $\begin{array}{r}0.9 \\
9\end{array}$ & $\begin{array}{r}- \\
0.8\end{array}$ & $\begin{array}{r}1.0 \\
0\end{array}$ & $\begin{array}{r}1.0 \\
0\end{array}$ & $\begin{array}{r}- \\
0.5 \\
1\end{array}$ & 1 & & & & & & \\
\hline Orbital height $(\mathrm{cm})$ & 0.7 & 0.6 & 0.5 & 0.8 & $0 . \overline{9}$ & 0.8 & 0.9 & $0 . \overline{1}$ & 0.8 & & & & & & \\
\hline Orbital width $(\mathrm{cm})$ & 5 & 4 & 6 & 3 & 0 & 9 & 1 & 4 & 7 & 1 & & & & & \\
\hline $\begin{array}{l}\text { Interorbital distance } \\
\text { (rostral) }(\mathrm{cm})\end{array}$ & $\begin{array}{r}0.7 \\
7\end{array}$ & $\begin{array}{r}0.9 \\
4\end{array}$ & $\begin{array}{r}0.5 \\
9\end{array}$ & $\begin{array}{r}0.7 \\
2\end{array}$ & $\begin{array}{r}0.6 \\
2\end{array}$ & $\begin{array}{r}0.6 \\
8\end{array}$ & $\begin{array}{r}0.6 \\
8\end{array}$ & $\begin{array}{r}0.4 \\
7\end{array}$ & $\begin{array}{r}0.7 \\
4\end{array}$ & $\begin{array}{r}0.3 \\
7\end{array}$ & 1 & & & & \\
\hline $\begin{array}{l}\text { Interorbital distance } \\
\text { (middle) }(\mathrm{cm})\end{array}$ & $\begin{array}{r}0.2 \\
2\end{array}$ & $\begin{array}{r}0.6 \\
9\end{array}$ & $\begin{array}{r}0.9 \\
9\end{array}$ & $\begin{array}{r}0.8 \\
2\end{array}$ & $\begin{array}{r}0.3 \\
0\end{array}$ & $\begin{array}{r}0.7 \\
8\end{array}$ & $\begin{array}{r}0.7 \\
1\end{array}$ & $\begin{array}{r}0.9 \\
3\end{array}$ & $\begin{array}{r}0.7 \\
5\end{array}$ & $\begin{array}{r}0.4 \\
9\end{array}$ & $\begin{array}{r}0.5 \\
0\end{array}$ & 1 & & & \\
\hline \multirow[t]{3}{*}{$\begin{array}{l}\text { Interorbital distance } \\
\text { (caudal) }(\mathrm{cm})\end{array}$} & $\begin{array}{r}0.6 \\
0\end{array}$ & $\begin{array}{r}0.4 \\
4\end{array}$ & $\begin{array}{r}0.4 \\
4\end{array}$ & $\begin{array}{r}0.7 \\
0\end{array}$ & $\begin{array}{r}0 . \overline{8} \\
0\end{array}$ & $\begin{array}{r}0.7 \\
7\end{array}$ & $\begin{array}{r}0.8 \\
0\end{array}$ & $\begin{array}{r}0.0 \\
2\end{array}$ & $\begin{array}{r}0.7 \\
3\end{array}$ & $\begin{array}{r}0.9 \\
7\end{array}$ & $\begin{array}{r}0.1 \\
3\end{array}$ & $\begin{array}{r}0.3 \\
9\end{array}$ & 1 & & \\
\hline & - & - & - & - & & - & - & - & - & - & - & - & - & & \\
\hline & 0.8 & 0.5 & 0.3 & 0.7 & 0.9 & 0.7 & 0.8 & 0.1 & 0.7 & 0.9 & 0.3 & 0.2 & 0.9 & & \\
\hline Cranial capacity (cc) & 1 & 6 & 4 & 1 & 4 & 8 & 3 & 0 & 7 & 7 & 2 & 6 & 5 & 1 & \\
\hline $\begin{array}{l}\text { Mandibular length } \\
(\mathrm{cm})\end{array}$ & $\begin{array}{r}0.8 \\
4 \\
\end{array}$ & $\begin{array}{r}0.1 \\
3\end{array}$ & $\begin{array}{r}0.9 \\
4\end{array}$ & $\begin{array}{r}0.4 \\
3\end{array}$ & $\begin{array}{r}0.9 \\
2\end{array}$ & $\begin{array}{r}0.1 \\
2\end{array}$ & $\begin{array}{r}0 . \\
3\end{array}$ & $\begin{array}{r}0.9 \\
8\end{array}$ & $\begin{array}{r}0.0 \\
0\end{array}$ & $\begin{array}{r}- \\
0.5 \\
7\end{array}$ & $\begin{array}{r}0.0 \\
4\end{array}$ & $\begin{array}{r}0.9 \\
5\end{array}$ & $\begin{array}{r}0 . \overline{4} \\
8\end{array}$ & $\begin{array}{r}0 . \\
81\end{array}$ & 1 \\
\hline
\end{tabular}

Yellow blocks indicate a strong positive correlation; Green blocks indicate a strong negative correlation 


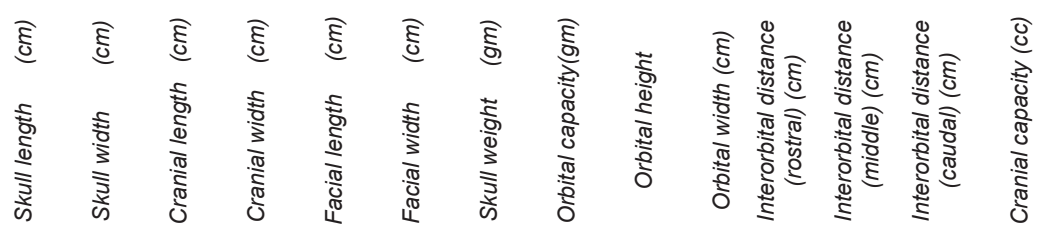

\begin{tabular}{|c|c|c|c|c|c|c|c|c|c|c|c|c|c|c|}
\hline $\begin{array}{ll}\text { Skull length } & (\mathrm{cm}) \\
\text { Skull width } & (\mathrm{cm})\end{array}$ & $\begin{array}{r}1.0 \\
0 \\
0.9 \\
2\end{array}$ & $\begin{array}{r}1.0 \\
0\end{array}$ & & & & & & & & & & & & \\
\hline Cranial length $(\mathrm{cm})$ & $\begin{array}{r}0.1 \\
7\end{array}$ & $\begin{array}{r}0.2 \\
1\end{array}$ & $\begin{array}{r}1.0 \\
0\end{array}$ & & & & & & & & & & & \\
\hline Cranial width $(\mathrm{cm})$ & & $\begin{array}{r}0.8 \\
2\end{array}$ & $\begin{array}{r}0.3 \\
6\end{array}$ & $\begin{array}{r}1.0 \\
0\end{array}$ & & & & & & & & & & \\
\hline Facial length $\quad(\mathrm{cm})$ & $\begin{array}{r}0.9 \\
6\end{array}$ & $\begin{array}{r}0.9 \\
9\end{array}$ & $\begin{array}{r}0.1 \\
2 \\
0\end{array}$ & $\begin{array}{r}0.8 \\
5\end{array}$ & $\begin{array}{r}1.0 \\
0 \\
0\end{array}$ & & & & & & & & & \\
\hline Facial width $\quad(\mathrm{cm})$ & $\begin{array}{r}0.9 \\
4\end{array}$ & $\begin{array}{r}0.7 \\
4\end{array}$ & $\begin{array}{r}0.4 \\
7\end{array}$ & $\begin{array}{r}0.5 \\
9\end{array}$ & $\begin{array}{r}0.8 \\
1\end{array}$ & $\begin{array}{r}1.0 \\
0\end{array}$ & & & & & & & & \\
\hline Skull weight $\quad(\mathrm{gm})$ & $\begin{array}{r}0.7 \\
0\end{array}$ & $\begin{array}{r}0.4 \\
0\end{array}$ & $\begin{array}{r}0.8 \\
1\end{array}$ & $\begin{array}{r}0.1 \\
1\end{array}$ & $\begin{array}{r}0.4 \\
7\end{array}$ & $\begin{array}{r}0.8 \\
6\end{array}$ & $\begin{array}{r}1.0 \\
0\end{array}$ & & & & & & & \\
\hline Orbital capacity(gm) & $\begin{array}{r}0.5 \\
3\end{array}$ & $\begin{array}{r}0.5 \\
1\end{array}$ & $\begin{array}{r}0.1 \\
9\end{array}$ & $\begin{array}{r}0.9 \\
0\end{array}$ & $\begin{array}{r}0.5 \\
9\end{array}$ & $\begin{array}{r}0.5 \\
0\end{array}$ & $\begin{array}{r}0.0 \\
5\end{array}$ & $\begin{array}{r}1.0 \\
0\end{array}$ & & & & & & \\
\hline Orbital height & $\begin{array}{r}0.9 \\
1\end{array}$ & $\begin{array}{r}0.9 \\
6\end{array}$ & $\begin{array}{r}0.0 \\
9\end{array}$ & $\begin{array}{r}0.6 \\
3\end{array}$ & $\begin{array}{r}0.9 \\
4\end{array}$ & $\begin{array}{r}0.7 \\
3\end{array}$ & $\begin{array}{r}0.5 \\
1\end{array}$ & $\begin{array}{r}0.2 \\
7\end{array}$ & $\begin{array}{r}1.0 \\
0\end{array}$ & & & & & \\
\hline Orbital width $(\mathrm{cm})$ & $\begin{array}{r}0.9 \\
8\end{array}$ & $\begin{array}{r}0.8 \\
3\end{array}$ & $\begin{array}{r}0.3 \\
5\end{array}$ & $\begin{array}{r}0.6 \\
6\end{array}$ & $\begin{array}{r}0.8 \\
9\end{array}$ & $\begin{array}{r}0.9 \\
9\end{array}$ & $\begin{array}{r}0.8 \\
1\end{array}$ & $\begin{array}{r}0.5 \\
0\end{array}$ & $\begin{array}{r}0.8 \\
3\end{array}$ & $\begin{array}{r}1.0 \\
0\end{array}$ & & & & \\
\hline $\begin{array}{l}\text { Interorbital distance } \\
(\text { rostral) }(\mathrm{cm})\end{array}$ & $\begin{array}{r}0.4 \\
4\end{array}$ & $\begin{array}{r}0.1 \\
2\end{array}$ & $\begin{array}{r}0.9 \\
2\end{array}$ & $\begin{array}{r}0.2 \\
0\end{array}$ & $\begin{array}{r}0.1 \\
8\end{array}$ & $\begin{array}{r}0.6 \\
7\end{array}$ & $\begin{array}{r}0.9 \\
5\end{array}$ & $\begin{array}{r}0.2 \\
0\end{array}$ & $\begin{array}{r}0.2 \\
7\end{array}$ & $\begin{array}{r}0.5 \\
9\end{array}$ & $\begin{array}{r}1 . \\
00\end{array}$ & & & \\
\hline $\begin{array}{l}\text { Interorbital distance } \\
(\text { middle) }(\mathrm{cm})\end{array}$ & $\begin{array}{r}0.9 \\
6\end{array}$ & $\begin{array}{r}0.8 \\
0\end{array}$ & $\begin{array}{r}0.3 \\
5\end{array}$ & $\begin{array}{r}0.7 \\
0\end{array}$ & $\begin{array}{r}0.8 \\
7\end{array}$ & $\begin{array}{r}0.9 \\
9\end{array}$ & $\begin{array}{r}0.7 \\
8\end{array}$ & $\begin{array}{r}0.6 \\
0\end{array}$ & $\begin{array}{r}0.7 \\
6\end{array}$ & $\begin{array}{r}0.9 \\
9\end{array}$ & $\begin{array}{r}0 . \\
55\end{array}$ & $\begin{array}{r}1.0 \\
0\end{array}$ & & \\
\hline $\begin{array}{l}\text { Interorbital distance } \\
(\text { caudal })(\mathrm{cm})\end{array}$ & $\begin{array}{r}0.2 \\
3\end{array}$ & $\begin{array}{r}0.1 \\
4\end{array}$ & $\begin{array}{r}0.8 \\
0\end{array}$ & $\begin{array}{r}0.0 \\
7\end{array}$ & $\begin{array}{r}0.0 \\
0\end{array}$ & $\begin{array}{r}0.5 \\
3\end{array}$ & $\begin{array}{r}0.6 \\
1\end{array}$ & $\begin{array}{r}0.3 \\
8\end{array}$ & $\begin{array}{r}0.1 \\
9\end{array}$ & $\begin{array}{r}0.3 \\
9\end{array}$ & $\begin{array}{r}0 . \\
62\end{array}$ & $\begin{array}{r}0.4 \\
8\end{array}$ & $\begin{array}{r}1.0 \\
0\end{array}$ & \\
\hline Cranial capacity (cc) & $\begin{array}{r}0.2 \\
9 \\
\end{array}$ & $\begin{array}{r}0.2 \\
6 \\
\end{array}$ & $\begin{array}{r}0.1 \\
7 \\
\end{array}$ & $\begin{array}{r}0.7 \\
5 \\
\end{array}$ & $\begin{array}{r}0.3 \\
4 \\
\end{array}$ & $\begin{array}{r}0.3 \\
1 \\
\end{array}$ & $\begin{array}{r}0.0 \\
9 \\
\end{array}$ & $\begin{array}{r}0.9 \\
6 \\
\end{array}$ & $\begin{array}{r}0.0 \\
0 \\
\end{array}$ & $\begin{array}{r}0.2 \\
9 \\
\end{array}$ & $\begin{array}{r}0 . \\
29 \\
\end{array}$ & $\begin{array}{r}0.4 \\
1 \\
\end{array}$ & $\begin{array}{r}0.4 \\
5 \\
\end{array}$ & $\begin{array}{r}1 . \\
00 \\
\end{array}$ \\
\hline
\end{tabular}

Yellow blocks indicate a strong positive correlation; Green blocks indicate a strong negative correlation 


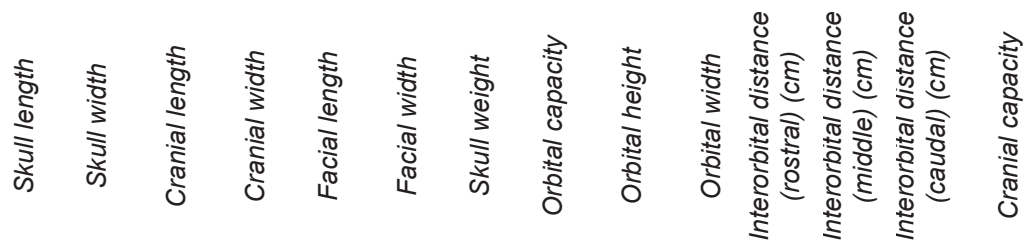

\begin{tabular}{|c|c|c|c|c|c|c|c|c|c|c|c|c|c|c|}
\hline Skull length & $\begin{array}{r}1.0 \\
0\end{array}$ & & & & & & & & & & & & & \\
\hline Skull width & $\begin{array}{r}0.5 \\
7\end{array}$ & $\begin{array}{r}1.0 \\
0\end{array}$ & & & & & & & & & & & & \\
\hline & 0.4 & 0.4 & 1.0 & & & & & & & & & & & \\
\hline Cranial length & 6 & 4 & 0 & & & & & & & & & & & \\
\hline Cranial width & $\begin{array}{r}0.3 \\
6\end{array}$ & $\begin{array}{r}0.0 \\
6\end{array}$ & $\begin{array}{r}0.3 \\
0\end{array}$ & $\begin{array}{r}1.0 \\
0\end{array}$ & & & & & & & & & & \\
\hline Facial length & $\begin{array}{r}0.7 \\
7\end{array}$ & $\begin{array}{r}0.4 \\
5\end{array}$ & $\begin{array}{r}- \\
0.1 \\
2\end{array}$ & $\begin{array}{r}0.0 \\
3\end{array}$ & $\begin{array}{r}1.0 \\
0\end{array}$ & & & & & & & & & \\
\hline & 0.5 & 0.3 & 0.4 & 0.1 & 0.3 & 1.0 & & & & & & & & \\
\hline Facial width & 5 & 8 & 4 & 4 & 0 & 0 & & & & & & & & \\
\hline Skull weight & $\begin{array}{r}0.2 \\
8\end{array}$ & $\begin{array}{r}0.2 \\
6\end{array}$ & $\begin{array}{r}0.5 \\
3\end{array}$ & $\begin{array}{r}0.0 \\
3\end{array}$ & $\begin{array}{r}0.0 \\
1\end{array}$ & $\begin{array}{r}0.6 \\
9\end{array}$ & $\begin{array}{r}1.0 \\
0\end{array}$ & & & & & & & \\
\hline Orbital capacity & $\begin{array}{r}0.8 \\
3\end{array}$ & $\begin{array}{r}0.5 \\
8\end{array}$ & $\begin{array}{r}0.2 \\
9\end{array}$ & $\begin{array}{r}0.3 \\
1\end{array}$ & $\begin{array}{r}0.6 \\
7\end{array}$ & $\begin{array}{r}0.3 \\
9\end{array}$ & $\begin{array}{r}0.4 \\
0\end{array}$ & $\begin{array}{r}1.0 \\
0\end{array}$ & & & & & & \\
\hline Orbital height & $\begin{array}{r}0.2 \\
0\end{array}$ & $\begin{array}{r}0.3 \\
3\end{array}$ & $\begin{array}{r}0.0 \\
8\end{array}$ & $\begin{array}{r}- \\
0.1 \\
3 \\
-\end{array}$ & $\begin{array}{r}0.3 \\
3\end{array}$ & $\begin{array}{r}- \\
0.1 \\
2\end{array}$ & $\begin{array}{r}0.3 \\
4\end{array}$ & $\begin{array}{r}0.5 \\
0\end{array}$ & $\begin{array}{r}1.0 \\
0\end{array}$ & & & & & \\
\hline Orbital width & $\begin{array}{r}0.3 \\
3\end{array}$ & $\begin{array}{r}0.4 \\
6\end{array}$ & $\begin{array}{r}0.4 \\
6\end{array}$ & $\begin{array}{r}0.0 \\
2\end{array}$ & $\begin{array}{r}0.1 \\
9\end{array}$ & $\begin{array}{r}0.5 \\
6\end{array}$ & $\begin{array}{r}0.3 \\
6\end{array}$ & $\begin{array}{r}0.0 \\
1\end{array}$ & $\begin{array}{r}0.0 \\
8\end{array}$ & $\begin{array}{r}1.0 \\
0\end{array}$ & & & & \\
\hline $\begin{array}{l}\text { Interorbital distance } \\
\text { (rostral) }(\mathrm{cm})\end{array}$ & $\begin{array}{r}0.1 \\
1\end{array}$ & $\begin{array}{r}0.3 \\
4\end{array}$ & $\begin{array}{r}- \\
0.1 \\
4\end{array}$ & $\begin{array}{r}- \\
0.3 \\
3\end{array}$ & $\begin{array}{r}0.4 \\
2\end{array}$ & $\begin{array}{r}0.2 \\
4\end{array}$ & $\begin{array}{r}0.0 \\
5\end{array}$ & $\begin{array}{r}0.0 \\
6\end{array}$ & $\begin{array}{r}0.0 \\
9\end{array}$ & $\begin{array}{r}0.4 \\
4\end{array}$ & $\begin{array}{r}1.0 \\
0\end{array}$ & & & \\
\hline $\begin{array}{l}\text { Interorbital distance } \\
\text { (middle) }(\mathrm{cm})\end{array}$ & $\begin{array}{r}0.4 \\
7\end{array}$ & $\begin{array}{r}0.5 \\
5\end{array}$ & $\begin{array}{r}0.3 \\
5\end{array}$ & $\begin{array}{r}0.2 \\
2\end{array}$ & $\begin{array}{r}0.3 \\
6\end{array}$ & $\begin{array}{r}0.6 \\
3\end{array}$ & $\begin{array}{r}0.4 \\
5\end{array}$ & $\begin{array}{r}0.4 \\
8\end{array}$ & $\begin{array}{r}0.0 \\
6\end{array}$ & $\begin{array}{r}0.4 \\
3\end{array}$ & $\begin{array}{r}0.6 \\
8\end{array}$ & $\begin{array}{r}1.0 \\
0\end{array}$ & & \\
\hline $\begin{array}{l}\text { Interorbital distance } \\
\text { (caudal) }(\mathrm{cm})\end{array}$ & $\begin{array}{r}0.2 \\
9\end{array}$ & $\begin{array}{r}0.4 \\
9\end{array}$ & $\begin{array}{r}0.2 \\
2\end{array}$ & $\begin{array}{r}0.2 \\
1\end{array}$ & $\begin{array}{r}0.2 \\
3\end{array}$ & $\begin{array}{r}0.2 \\
7\end{array}$ & $\begin{array}{r}0.3 \\
6\end{array}$ & $\begin{array}{r}0.5 \\
5\end{array}$ & $\begin{array}{r}0.2 \\
6\end{array}$ & $\begin{array}{r}0.0 \\
2\end{array}$ & $\begin{array}{r}0.4 \\
3\end{array}$ & $\begin{array}{r}0.7 \\
6\end{array}$ & $\begin{array}{r}1.0 \\
0\end{array}$ & \\
\hline Cranial capacity & $\begin{array}{r}0.6 \\
6 \\
\end{array}$ & $\begin{array}{r}0.2 \\
8 \\
\end{array}$ & $\begin{array}{r}0.4 \\
1 \\
\end{array}$ & $\begin{array}{r}0.5 \\
6 \\
\end{array}$ & $\begin{array}{r}0.2 \\
6 \\
\end{array}$ & $\begin{array}{r}0.1 \\
4 \\
\end{array}$ & $\begin{array}{r}0.0 \\
0 \\
\end{array}$ & $\begin{array}{r}0.6 \\
0 \\
\end{array}$ & $\begin{array}{r}0.1 \\
1\end{array}$ & $\begin{array}{r}0.0 \\
7 \\
\end{array}$ & $\begin{array}{r}0.2 \\
2 \\
\end{array}$ & $\begin{array}{r}0.2 \\
1 \\
\end{array}$ & $\begin{array}{r}0.3 \\
5\end{array}$ & $\begin{array}{r}1.0 \\
0\end{array}$ \\
\hline
\end{tabular}

Yellow blocks indicate a strong positive correlation 
Table (9): Covariance estimates for the various morphometric measurements taken for lion, cat and dog skulls

\begin{tabular}{|c|c|c|c|c|c|}
\hline \multicolumn{3}{|l|}{ Measurement } & \multirow{2}{*}{$\begin{array}{r}\text { Lion skulls } \\
0.03\end{array}$} & \multirow{2}{*}{$\begin{array}{r}\text { Cat skulls } \\
0.17\end{array}$} & \multirow{2}{*}{$\begin{array}{r}\text { Dog skulls } \\
0.07\end{array}$} \\
\hline Skull length & (cm) & & & & \\
\hline Skull width & $(\mathrm{cm})$ & & 0.08 & 0.21 & 0.06 \\
\hline Cranial length & $(\mathrm{cm})$ & & 0.25 & 0.12 & 0.11 \\
\hline Cranial width & $(\mathrm{cm})$ & & 0.17 & 0.06 & 0.07 \\
\hline Facial length & $(\mathrm{cm})$ & & 0.33 & 0.29 & 0.06 \\
\hline Facial width & $(\mathrm{cm})$ & & 0.29 & 0.20 & 0.07 \\
\hline Skull weight & (gm) & & 0.26 & 0.39 & 0.29 \\
\hline Orbital capacity & (gm) & & 0.27 & 0.41 & 0.29 \\
\hline Orbital height & $(\mathrm{cm})$ & & 0.06 & 0.23 & 0.09 \\
\hline Orbital width & $(\mathrm{cm})$ & & 0.09 & 0.12 & 0.07 \\
\hline \multicolumn{2}{|c|}{ Interorbital distance (rostral) } & $(\mathrm{cm})$ & 0.22 & 2.14 & 0.12 \\
\hline \multicolumn{2}{|c|}{ Interorbital distance (middle) } & $(\mathrm{cm})$ & 0.08 & 0.15 & 0.24 \\
\hline \multicolumn{2}{|c|}{ Interorbital distance (caudal) } & $(\mathrm{cm})$ & 0.25 & 0.06 & 7.76 \\
\hline Cranial capacity & (cc) & & 0.12 & 0.09 & 0.14 \\
\hline
\end{tabular}
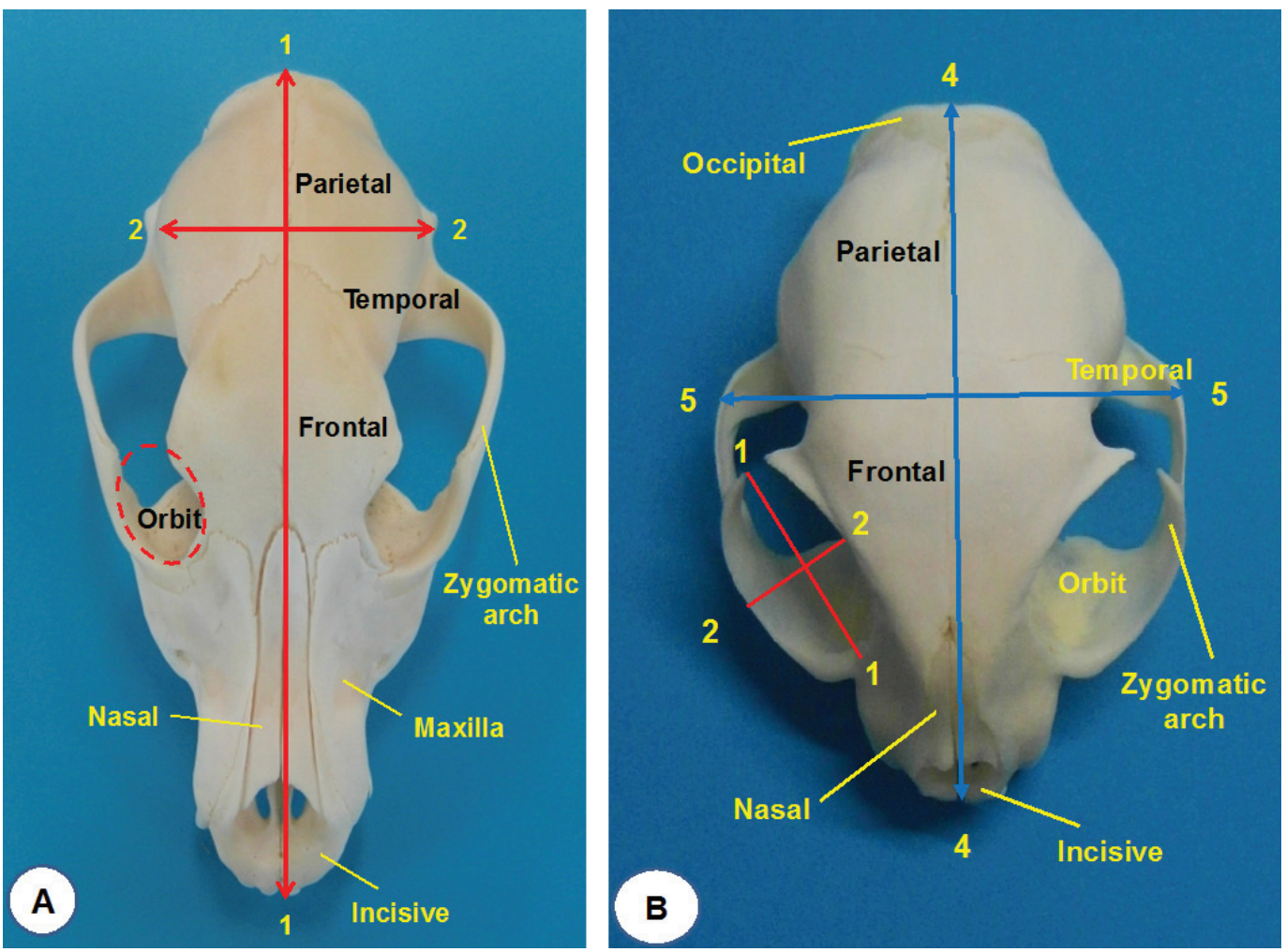

Plate (1): Measurements taken for the dog, cat and lion skulls.

(A) Dorso-ventral view of dog skull: 1-1Cranial length, 2-2 Cranial width \&

(B) Dorso-ventral view of cat skull: 1-1 orbital length, 2-2 orbital width, 4-4 skull length, 5-5 skull width 


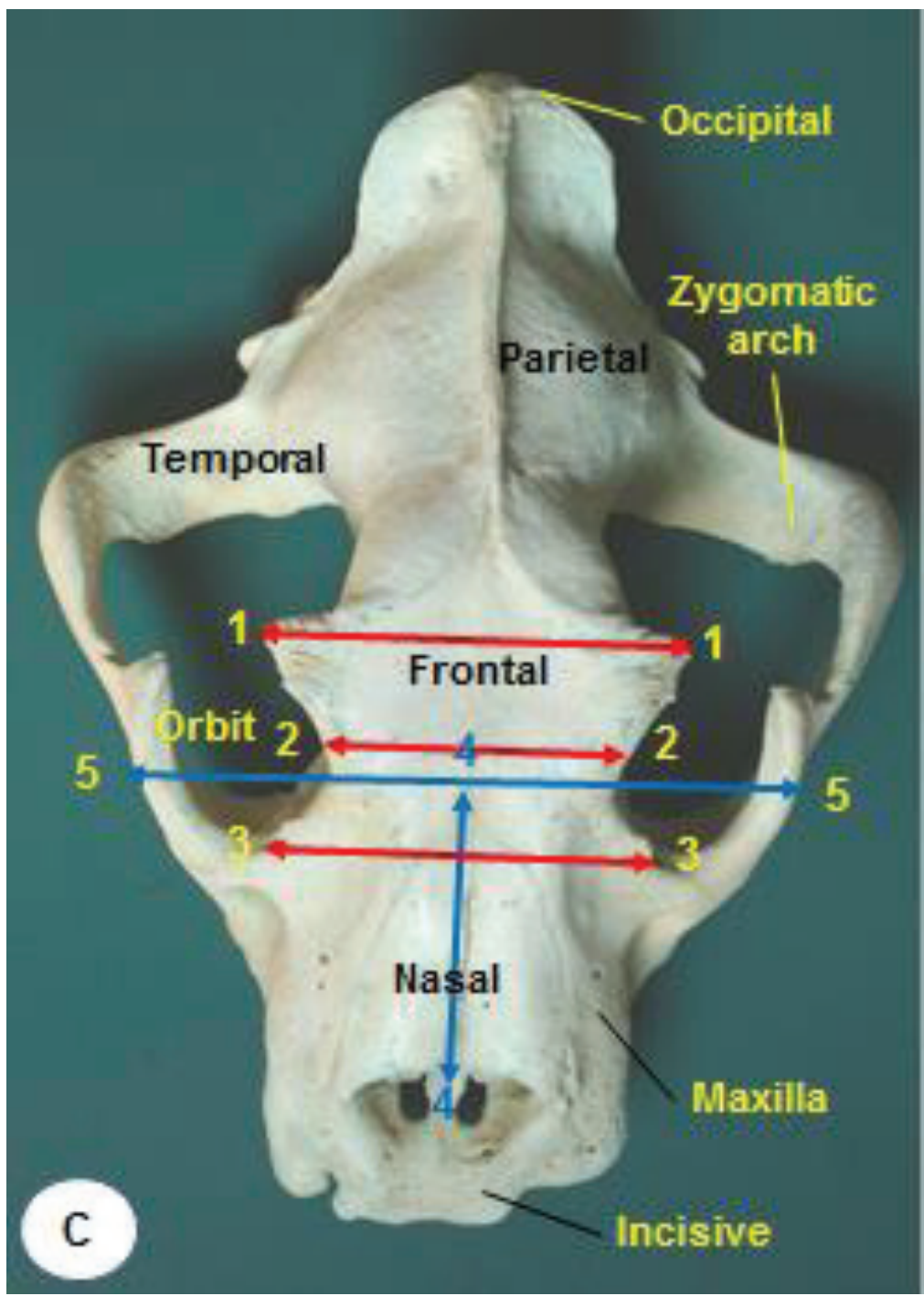

Plate (1): Measurements taken for the dog, cat and lion skulls.

(C) Dorso-ventral view of lion skull: 1-1 caudal interorbital distance, 2-2 middel interorbital distance, 3-3 rostral interorbital distance, 4-4 facial length, 5-5 facial width.

\section{Corresponding author:}

saberashraf_2@yahoo.com 